\title{
TRANSACTION COSTS IN THE PHARMACEUTICAL RETAIL MARKET: IMPACTS OF OPPORTUNISM AND ANALYTICAL DIMENSIONS OF TRANSACTIONS ${ }^{1}$
}

\author{
ADILSON A. SILVA ${ }^{2}$ \\ (iD) https://orcid.org/0000-0001-7029-0742
}

To cite this paper: Silva, A. A. (2021). Transaction costs in the pharmaceutical retail market: Impacts of opportunism and analytical dimensions of transactions. Revista de Administração Mackenzie, 22(4), 1-29. doi:10.1590/1678-6971/eRAMR210037

Submission: Mar. 10, 2020. Acceptance: Oct. 9, 2020.

To the Mackenzie Research Fund for promoting this research, and to the professors: Dr. Andresa Silva Neto Francischini, Dr. Douglas Dias Bastos, Dr. Eraldo Genin Fiori, and MSc. Ricardo Alves de Souza for the fruitful contributions and revisions proposed in the elaboration of this paper.

2 Mackenzie Presbyterian University (UPM), São Paulo, SP, Brazil.

\section{(cc) BY




\section{ABSTRACT}

Purpose: The study explores the predictive relationships of the analytical dimensions of transactions and opportunistic behavior on the transaction costs of the Brazilian pharmaceutical retail market.

Originality/value: The study contributes to the advancement of empirical research on the subject and proposes indicators modeled by structural equations to simultaneously estimate the effects of uncertainty, asset specificity and frequency of transactions, and opportunism in transaction costs.

Design/methodology/approach: Transaction costs were estimated with indicators related to the costs of analysis, preparation, and adaptation of contracts; these are analytical dimensions of transactions with indicators that reflect the specificity of human assets and physical/dedicated assets, technological and market uncertainty, and the recurrence of transactions between partners. The data collected via an electronic questionnaire were processed with the technique of Modeling in Structural Equations.

Results: Data processing demonstrated the significant influence of the frequency of transactions on opportunism and hence on transaction costs. It also confirmed the impact of uncertainty on ex ante transaction costs and the specificity of assets on ex post costs. The results denote the relevance of analytical dimensions in the theoretical framework of Transaction Cost Theory and the importance of frequency as a catalyst for opportunism. It can be used as a parameter in strategic actions to create reliable commitments and circumvent unforeseen contractual failures in the pharmaceutical retail market.

\section{KEYWORDS}

Transaction costs. Pharmaceutical retail market. Opportunism. Transaction dimensions. Governance structures. 


\section{INTRODUCTION}

Over the past few decades, the Transaction Cost Theory (TCT) has gained recognition for identifying the choice of efficient governance mechanisms to coordinate a company's productive resources with lower transaction costs.

This theoretical approach, structured by Oliver Williamson in the 1970s, is based on the assumptions of limited rationality and opportunistic behavior of agents and has as a unit of analysis, the transaction, characterized by objective attributes such as idiosyncratic investments, those in which much of the economic value is lost when reemployed out of context or to another activity, uncertainty in the business environment, and the frequency of transactions performed.

Williamson (1991) proposed a model to explain the transaction costs of each governance structure according to the assets' level of specificity. This model forms a continuum of governance structures by increasing the degree of vertical integration. However, in this model, the existence of uncertainty and frequency of transactions at a constant level capable of causing contractual adaptations and transaction costs is assumed.

The importance of TCT is highlighted by several studies that have sought to test and validate its assumptions and dimensions. Skarmeas, Katsikeas, and Schlegelmilch (2002) tested the impact of opportunism, uncertainty, and investments in specific assets on importers' and suppliers' degree of commitment. Carson, Madhok, and Wu (2006) compared the effectiveness of contractual and relational governance to curb opportunism in coordinating specific assets in uncertain environments. Marcher and Richman (2008) evidenced the relevance of studies that used specific assets and uncertainty as explanatory variables of transaction costs. Also noteworthy are studied by Barzel (1997), which related transaction costs to property rights, Furubotn and Richter (2000) linked transaction costs to the costs of using the market price mechanism, management costs, and costs of political transactions in institutional changes, Grover and Malhotra (2003) developed an instrument to estimate transaction costs based on the perception of managers about the efforts associated with the development and monitoring of partner performance and conflict resolution, and Barthélemy and Quélin (2006) estimated transaction costs with indicators related to the proximity of partners to the core of the business and the costs of change and contractual adaptation.

In Brazil, we highlight the studies conducted by Lazzarini, Zylbersztajn, and Takaki (1998) on the effect of contractual innovations in the future of 
the beef market, by Zylbersztajn and Graça (2003) and Zylbersztajn (2010) on the costs of founding companies as a proxy for ex ante transaction costs, by Claro and Claro (2004) that tested the importance of trust and the effect of investments in specific assets in collaborative relationships with suppliers; and by Lazzarini et al. (1998), who analyzed the factors responsible for the coexistence of different governance structures under reduced specificity of the assets in the chicken production chain.

Caleman, Sproesser, Lima, and Tredezin (2006) highlight the measurement of transaction costs as a theoretical gap to be met. In this sense, Serigati and Azevedo (2014) combined cointegration models to measure transaction costs in the international ethanol market. Bánkuti, Souza, and Bánkuti (2008) analyzed transaction costs in relations between rural producers and agents of the formal and informal market in the Agroindustrial Milk System (AMS). Silva and Brito (2013) evaluated the impact of uncertainty, the limited rationality, and the specificity of the assets in opportunistic behavior in supply chains. Schubert and Waquil (2014) showed the weight of asset specificity in increasing transaction costs and the contribution of frequency to minimize costs in milk production cooperatives in western Santa Catarina. Finally, Kilinsky and Souza (2016) measured managers' perception of transaction costs in outsourcing processes in financial institution back-office areas.

Also noteworthy are the studies by Lodi (2018), that highlight the importance of the TCT in the definition of organizational strategy, by Bezerra (2018), that evidenced the recurrence of purchase transactions in the salt industry as a factor of good performance in negotiations and favoring partnerships with suppliers, by Melo, Sales, Oliveira, Almeida, and Souza (2018), who identified the importance of the frequency of transactions in reducing transaction costs in the activities of exporting companies in the melon segment, by Oliveira, Sales, Oliveira, Bezerra, and Souza (2019), which evidenced the recurrence of transactions as a facilitator of the value of the product in the salt industry, and the study by Fernandes (2020), which investigated the cost of transaction in the composition of the total costs of açaí (a typical northern Brazilian fruit) points of sale in the city of Belém, in the state of Pará.

The focus of these studies is directed to the analysis of the proposed relationships between the analytical dimensions of transactions and behavioral assumptions of TCT with transaction costs; however, the influences of these dimensions and assumptions are usually evaluated quantitatively in isolation or qualitatively evidenced through case studies, resulting in fragmented analyses or propositions to be tested. 
The general objective of this study is to simultaneously test the predictive relationships defended in TCT between the analytical dimensions of transactions (uncertainty, asset specificity, and frequency), opportunistic behavior, and transaction costs, focusing on the Brazilian pharmaceutical retail market. To this end, specific objectives were established: 1 . to estimate transaction costs; 2 . to estimate the analytical dimensions of transactions using indicators that reflect the specificity of the assets, the uncertainty, and frequency of transactions; 3 . to estimate the opportunistic behavior of managers of the Brazilian pharmaceutical retail market; and 4. to develop a theoretical model to test the relationships proposed in the study simultaneously.

\section{THEORETICAL FRAMEWORK}

This section presents the definitions of transaction costs and the fundamental foundations of TCT, its behavioral assumptions, analytical dimensions, and the proposed relationships between them and transaction costs.

\subsection{Transaction costs}

Transaction costs are present from the first stages of a production process to the final marketing of the product or service. In the view of Coase (1937), these costs include expenses related to transfers and interactions with the market in search of relevant prices appropriate to the negotiation. The author argues that the use of the market price mechanism does not occur without costs but involves expenses related to the information collection, evaluation of transaction attributes, mapping of the advantages of negotiated products, preparation, monitoring, coordination, and execution of contracts with partners.

Williamson (1985) also related transaction costs to those incurred in contractual relations between economic agents incurred in planning, adaptation, and monitoring of contractual relationships and categorized them into 1. ex ante costs, to seek, prepare, negotiate, and protect a transaction and; 2. ex post costs, arising from monitoring, adjustment, and adaptation of transactions to changes caused by errors, omissions, unexpected changes, and contested contracts.

Therefore, the transaction costs arising from the preparation and negotiation of contracts, measurement and supervision of property rights, and monitoring of the partner's performance. That is, they are associated with 
engagement in transactions and contractual activities (Polski \& Kearney, 2001). Pilling, Crosby, and Jackson (1994) associate these costs with developing and maintaining an exchange relationship, monitoring, and protection against opportunism.

In this study, transaction costs include those incurred with the development, coordination, maintenance, monitoring, and contractual safeguards to discourage opportunistic behaviors in the exchange situation. This definition encompasses the costs of establishing the role of partners in relationships; the costs of research to identify exchange options; the acquisition of timely, accurate, and relevant information to evaluate, negotiate, and draft a contract; the costs of efforts to access and establish the expected role of a partner; the monitoring and evaluation of transaction performance; and the costs of promoting the productive effort, incentives and investments to deter unproductive negotiations and opportunistic behaviors.

From the definition of transaction costs, the theoretical framework that underlies the analysis of these costs is presented to establish mechanisms to minimize them.

\subsection{Transaction Cost Theory}

In TCE, there is a focus on contracts that are essentially elaborated incompletely due to uncertainty during negotiation or to the difficulty in predicting developments in the contractual relationship. According to Williamson (1985), after the conclusion of contracts, inefficiencies can arise due to changes in behavior and information asymmetries between partners.

Williamson (1985) outlined two behavioral assumptions for the elaboration of TCT: limited rationality and opportunistic behavior of agents in transactions. Despite the best efforts to deal with complexity and unpredictability, these agents are limited in their ability, knowledge, and skills to make accurate predictions and plan contingencies for changes in the contractual relationship. These agents' actions are restricted to the limits of human capacity; despite rational intent, people act in a limited way (Simon, 1958). Therefore, contracts are incomplete, and these gaps give rise to opportunistic behavior in negotiations.

Opportunistic behavior is defined as an intentional action "in which economic agents seek their interests in transactions, act for their benefit by taking advantage of contractual gaps or omissions to the detriment of partners" (Williamson, 1985, p. 47). 
The opportunism of agents is manifested by the strategic manipulation of information or distortion of intentions. A priori, managers will not hesitate to lie, cheat, omit, and distort information to achieve their goals (Williamson, 1985). However, elements such as culture, contractual safeguards, property rights, trust, and reputation present in the institutional environment can influence individuals' behavior, reducing or intensifying opportunistic behavior, thus, influencing contractual complexity (Schubert \& Waquil, 2014).

According to Santos, Lourenzani, and Lourenzani (2019, p. 115), opportunistic behavior "is not predictable, and does not even assume conventional patterns found in the organizational environment", and may occur ex ante or ex post the preparation of contracts, according to the degree of information asymmetry between agents, the complexity of the trading environment and the attributes of transactions, such as uncertainty, frequency, and specificity of assets.

Opportunistic behavior is the essence of TCT's explanation for the emergence of transaction costs because it is the gaps, errors, or contractual omissions, not foreseen or anticipated in the original contract exploited opportunistically by the economic agents involved, which result in the difficulties of managers to make adjustments and avoid market failures and transaction costs in the execution of contracts.

- Hypothesis 1: Opportunism positively impact transaction costs in the Brazilian pharmaceutical retail market.

Since in TCT the unit of analysis is the transaction, Williamson (1979) also considered it relevant to note that contractual negotiations are also subject to the objective attributes of transactions that differentiate them in their levels of complexity, among which the specificity of the assets, the frequency of transactions, and the uncertainty stand out. The level of variation of these analytical dimensions can enhance or minimize transaction costs, serving as parameters in the preparation of contracts and the choice of efficient governance structures to reduce such costs (Alencar, 2018).

\subsection{Analytical dimensions of transactions}

Firms own or need assets in their production processes, which allow them to make transactions with each other, sometimes creating a certain level of dependence between them. When these assets cannot be reemployed in other activities without significant economic value losses due to 
premature interruption, these assets are idiosyncratic and characterize the specificity of the assets (Williamson, 1991).

Specificity is one of the most critical attributes of transactions, as it creates "a conjuncture of reciprocal dependence among those involved in trading, increasing the risk of an unfinished transaction" (Melo et al., 2018). According to Williamson (1985, p. 86), "without the specific assets, the contract world would be greatly simplified, and TCT would lose most of its predictive power".

The specificity of the assets is classified into six different types: locational, associated with specific returns of proximity between companies; of physical assets, characterized by investments, in machinery, equipment, or facilities (Hoffmann, Neumann, \& Speckbacher, 2010; Nooteboom, Berger, \& Noorderhaven, 1997); of human assets, related to the specific qualifications and skills accumulated by employees (Hoffman et al., 2010; Hunter, Webster, \&Wyatt, 2005; Nooteboom et al., 1997); of dedicated assets, related to the amount of investment, the return of which depends on the transaction with a private agent (Azevedo, 2000; Hunter et al., 2005; Carson et al., 2006); the specificity of the brand materialized by long-term investments in the company's reputation; and the time associated with the time interval during which the transaction must be processed.

As asset specificity intensifies, the bilateral relationship between partners becomes increasingly complex due to the need to preserve the continuity of the relationship. In the search for an efficient adaptation to accommodate ex ante unforeseen changes and contingencies in the contract, intense and selfinterested negotiations may arise about the disposition and allocation of adaptive gains, thus generating ex post transaction costs to the parties involved (Riordan \& Williamson, 1985, p. 387).

Summing up, the increase in asset specificity implies a decrease in the reuse of the investment, greater bilateral dependence of agents, and greater need for adaptation to changes, making the continuity of the relationship valuable and potentially subject to ex post transaction costs.

- Hypothesis 2: Asset specificity positively impacts ex post transaction costs in the business environment of the Brazilian pharmaceutical retail market.

Despite its high predictive power, the specificity of assets alone is not sufficient to generate transaction costs; their relevance increases in uncertain environments in which the limits of rationality are highlighted. Uncertainty is also indicated as responsible for differences between transactions. 
The business environment is guided by unpredictable changes, scarcity, excess of information, or even information strategically distorted and disseminated to confuse competitors, making economic problems especially complex. In such circumstances, it is impossible to map all options and calculate all results of all actions or options given, making it impossible to accurately evaluate strategic decision-making (Knight, 2002; Azevedo, 2000; Oliveira, 2018; Santos \& Souza, 2017; Schubert \& Waquil, 2014).

In this way, Williamson (1985) distinguished uncertainty as primary uncertainty, associated with random environmental contingencies that emerge from nature and unpredictable changes in consumer preferences; and secondary uncertainty, related to the lack of information on the strategies or plans made by competitors and strategic or behavioral uncertainty attributed to opportunism or the particular characteristics of human actions in order to generate and disseminate distorted information, cover-up or mask information deliberately to confuse or succeed in negotiations.

Therefore, as the continuity of the relationship becomes an important factor in transactions and the disturbances caused by uncertainty begin to highlight the limits of the rationality of managers, complexity in the preparation of contracts, and the costs arising from interactions with the market in search of relevant and adequate prices in a given negotiation also increase (Coase, 1937; Williamson, 1985; Bánkuti et al., 2008; Silva \& Brito, 2013; Martins \& Souza, 2014; Folgueira, Silva, \& Carvalho, 2019).

- Hypothesis 3: Uncertainty positively impacts ex ante transaction costs in the business environment of the Brazilian pharmaceutical retail market.

Frequency is the third analytical dimension of transactions proposed by Williamson (1985). Characterized by the amount and regularity of times a contractual transaction occurs with a given partner, the frequency of transactions can increase trust and create a reliable compromise between partners, acting as safeguards to minimize opportunistic actions (Farina, Azevedo, \& Saes, 1997; Bánkuti et al., 2008; Santos et al., 2019).

Where there is a stable commitment between partners, this gives rise to and facilitates new transactions, compliance, and renewals of agreements already agreed based on transparency and communication between agents provided by the recurrence of transactions, which also allows gathering more excellent knowledge between parties in the negotiation, data collection, harmonization of information, and clarification of doubts, making operations safer, less burdensome and less in need of contractual safeguards to block opportunistic actions (Santos \& Souza, 2017; Santos et al., 2019). 
As Oliveira (2018, p. 4) point out, the "degree of recurrence [of a transaction] means that the parties involved are not motivated to opportunism in order to impose harm on their partners, since such action would result at the end of the transaction and generate financial losses in the future". According to Azevedo (2000, p. 38), "as transactions become recurrent, the parties may develop a reputation, which limits the interest in acting opportunistically to obtain short-term gains". In this scenario, the continuity of the relationship gains a particular relevance because of the expectation of future gains in transactions with specific assets by less costly and complex contractual mechanisms.

The frequency of transactions facilitates the adjustment of fundamental conditions to minimize the effects of contractual incompleteness and transaction costs, both ex ante in the preparation of contracts and ex post costs with incentives to execute and monitor contracts, and eliminate losses in case of breach of contracts (Schubert \& Waquil, 2014; Santos \& Souza, 2017). However, when calculating the frequency of transactions with a partner, one should consider: 1 . the level of reputation to be created as a means to limit opportunism for short-term gains and 2 . the possibility of avoiding the recurrence of costs related to the search of agents, contract preparation costs, signaling and scanning costs, so that these costs are lower in each transaction (Bánkuti et al., 2008; Raifur \& Garcias, 2008; Begnis, Arend, \& Alievi, 2017; Melo et al., 2018).

Therefore, investing in frequent relationships with a view to the continuity of the relationship can enable the flow of information, the acquisition of mutual knowledge between the parties, the creation of a reliable commitment, the construction of a reputation capable of circumventing the failures not covered by contracts and minimizing opportunistic behavior among economic agents in transactions (Farina et al., 1997; Santos et al., 2019).

- Hypothesis 4: The frequency of transactions negatively impacts opportunistic behavior in the business environment of the Brazilian pharmaceutical retail market.

Figure 2.3.1 illustrates the hypotheses established between the analytical dimensions of transactions, opportunism, and transaction costs in the business environment of the Brazilian pharmaceutical retail market. The following methodological procedures are presented to test these relationships. 


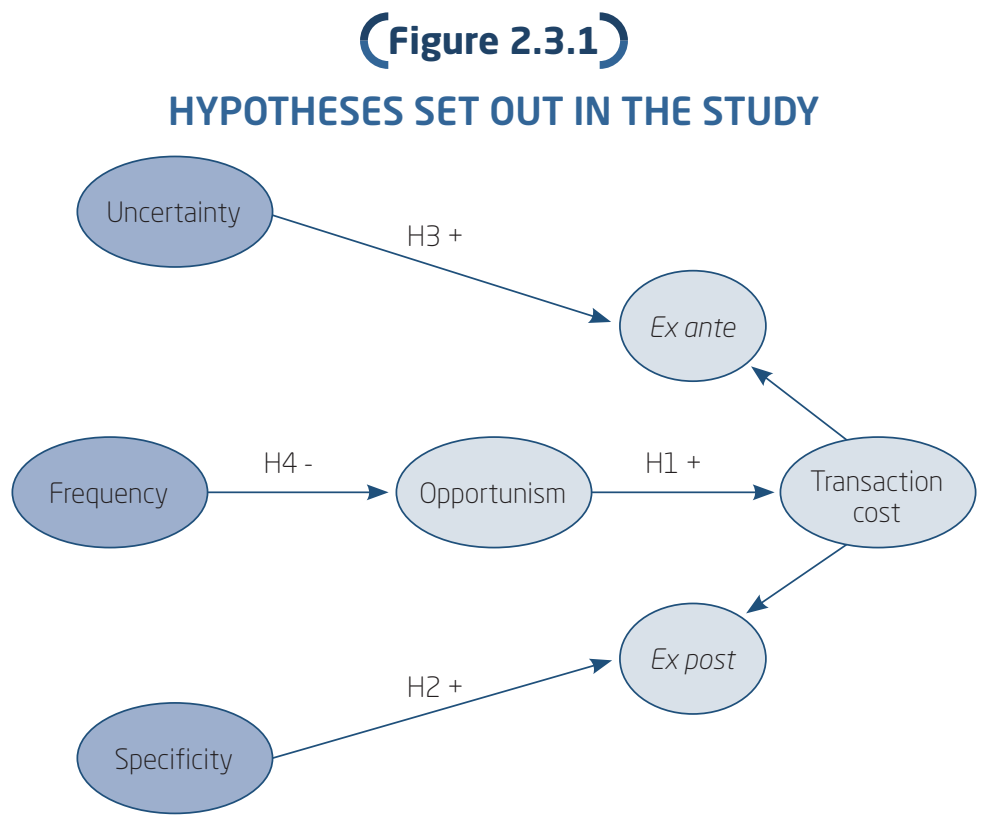

Source: Elaborated by the author.

\section{METHODOLOGICAL PROCEDURES}

The study involves the concomitant analysis of the relationships between the analytical dimensions of transactions, opportunistic behavior, and transaction costs. Considering the subjective nature of the constructs and the latent variables used in the study, we opted for data processing employing the multivariate statistical technique of Structural Equation Modeling, which combines multiple regression and factor analysis aspects to simultaneously evaluate the multiple dependency relationships and interrelationships between latent variables by specifying structural models (Hair, Anderson, Tatham, \& Black, 2009, p. 466).

Data processing, using the EQS 6.1 software, will employ the Maximum Likelihood method, taking into account the recommendations of Bentler and Chou (1987) regarding the processing of data from ordinal scales that introduce some degree of non-normality to the distribution due to the discrete nature of the data obtained. However, ordinal data with approximately normal distributions from scales with at least five categories can be treated as continuous data by the Maximum Likelihood Method or by the Maximum Likelihood Robust (ML ROBUST) method that adjusts the model by the Satorra-Bentler Scaled Chi-Square $\left(S B \chi^{2}\right)$ statistic and allows to determine reliable and equally 
stable statistics when data do not present normal distribution, and the sample is relatively small (Finney \& DiStefano, 2006; Bentler, 1995).

\subsection{Operationalization of research constructs}

The instrument for data collection, with indicators that reflect the constructs of interest in the study, was developed in three stages: 1. specification of the content and definition of the constructs, as suggested by Diamantopoulos and Winklhofer (2001) and Nunnally and Bernstein (1994); 2. selection of indicators that best reflected the analytical dimensions of transactions, opportunistic behavior, and transaction costs; and 3. translation, adequacy, and organization of these indicators on a five-point Likert scale, ranging from 1 (very low) to 5 (very high) to better capture the perception of the manager in the sector surveyed.

The indicators selected to capture the specificity of the assets reflect:

- the specificity of human assets in terms of specific investments aimed at training staff, information, and knowledge combined to create value, the need for expertise and know-how, and specific technical expertise of employees for the exercise of their activities (Hoffmann et al., 2010; Hunter et al., 2005; Nooteboom et al., 1997);

- the specificity of physical assets according to the degree of specific investments in the premises or equipment and the processes of marketing products (Hoffmann et al., 2010; Nooteboom et al., 1997).

Uncertainty indicators are related to the volatility of the business environment over time in terms of the level of unpredictability of market demand and the frequency of technological changes used in the commercialization of products (Carson et al., 2006). Regarding the frequency of transactions, indicators were selected that reflect the volume of transactions processed in a given exchange agreement (Williamson, 1985; Pilling et al., 1994) in terms of: 1 . the frequency of recurring transactions with current partners; 2 . the frequency of the same type of transaction with the same partner; and 3. the number of previous agreements with the main partners in other areas of activity.

For opportunistic behavior, in this study, three indicators, based on the literature consulted, that reflect the behavior of the transaction partner were elaborated regarding 1 . the predictability of performance in fulfilling agreed contracts, 2 . the level of use of contractual loopholes to renegotiate conditions for their benefit, and 3. the exaggeration of the costs they incur to try to renegotiate conditions that benefit them.

On the other hand, the operationalization of transaction costs was divided into ex ante costs, related to the development of the transaction with 
the obtaining of information, preparation, negotiation, and protection of an agreement, and ex post costs related to monitoring behavior in the transaction, also adjustments and adaptation due to changes in contract execution caused by failures, errors, omissions, and unexpected changes, and, finally, protection against opportunism (Williamson, 1985; Cunha, Saes, \& Mainville, 2015; Pilling et al., 1994;).

\subsection{Universe and research sample}

The research universe was defined by the set of pharmacies operating in the Brazilian Pharmaceutical Retail sector. The choice was due to the high number of transactions and strategic partnerships between pharmacies and suppliers' networks in various research and development, manufacturing, marketing, and distribution activities. Also, the representativeness of this segment in the Brazilian economy was considered in the choice.

According to data released by the Brazilian Federation of Associative and Independent Pharmacy Networks (Febrafar), in 2018, the total turnover of pharmacies in Brazil was BRL\$120.3 billion, and, according to the Brazilian Association of Drugstores Networks (Abrafarma, 2019), the large networks of the segment employed 130,757 employees and 24,333 pharmacists, and a had turnover of BRL $\$ 51.88$ billion in the period from August 2018 to October 2019.

For the field study, invitation letters were sent via e-mail to 6,548 pharmacy managers registered at the National Health Surveillance Agency (Anvisa). Of these invitation letters, there was a response from 173 managers who agreed to participate, which contacted by telephone by the team responsible for data collection for more detailed guidance on the research and the provision of the link to the electronic questionnaire. In the next section, the results obtained in the field research are presented.

\section{PRESENTATION AND ANALYSIS OF SURVEY RESULTS}

The survey was answered by 173 respondents, of whom 122 professionals reported their opinions comprehensively and consistently, thus, resulting in a final sample of 122 respondents. The descriptive analysis of the data indicated the predominance of male respondents (63.9\%), of whom $48.4 \%$ had higher education (undergraduate/graduate), compared to female respondents (36.1\%), of whom $33.5 \%$ have higher education (undergraduate/post-grad/ master/doctorate), and only $2.5 \%$ of them went to high school against $14.8 \%$ of men at that same level. 


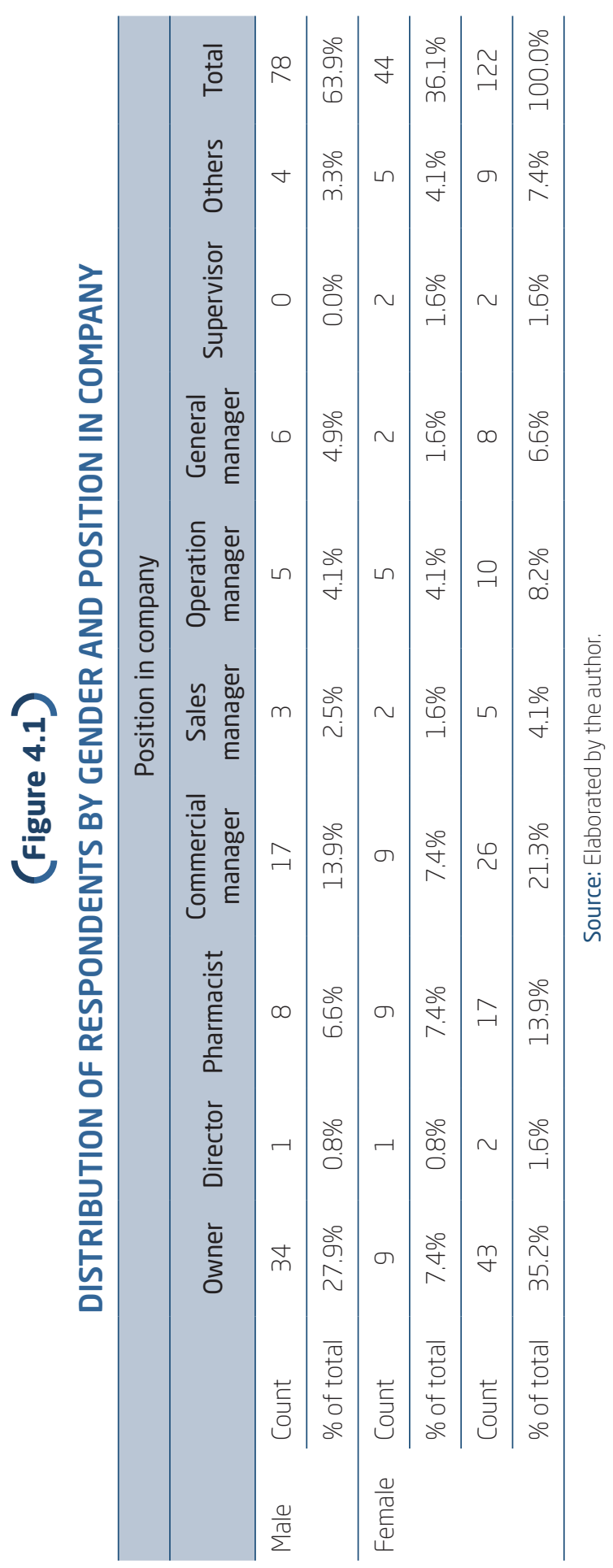


These data, together with the distribution of respondents by position, allow to verify the subjects' adequacy and qualification to provide relevant information about the constructs of the research; that is, 111 respondents (92.9\%) hold positions of middle or higher level. Of these, $38.8 \%$ are owners/ directors of the point of sale, $40.2 \%$ are managers, and $13.9 \%$ are pharmaceuticals. It is also verified that $27.9 \%$ of the owners are male, and $7.4 \%$ are women. Figure 4.2 shows the characterization of companies according to the number of points of sale and number of employees.

\section{(Figure 4.2)}

POINTS OF SALE AND NUMBER OF EMPLOYEES

\begin{tabular}{lccc}
\multicolumn{1}{c}{ Point of sale } & Frequency & Percent & Cumulative \% \\
\hline 1 point & 66 & 54.1 & 54.1 \\
\hline From 2 to 5 points & 23 & 18.9 & 73.0 \\
\hline From 5 to 10 points & 5 & 4.1 & 77.0 \\
\hline Above 10 points & 28 & 23.0 & 100 \\
\hline Total & 122 & 100 & Cumulative \% \\
\hline \multicolumn{1}{c}{ Employees } & Frequency & Percent & 69.7 \\
\hline From 1 to 50 & 85 & 69.7 & 79.5 \\
\hline From 50 to 99 & 12 & 9.8 & 86.1 \\
\hline From 100 to 500 & 8 & 6.6 & 100.0 \\
\hline Above 500 & 17 & 13.9 & \\
\hline Total & 122 & 100.0 & \\
\hline
\end{tabular}

Source: Elaborated by the author.

The majority of the sample $(54.1 \%)$ consists of companies with only one point of sale, and the small and medium-sized pharmacy chains with two to ten points of sale represent $22.9 \%$ of the sample. The rest $(23 \%)$ is made up of companies with ten or more points of sale. Regarding the number of employees, $69.7 \%$ of the companies employ up to 50 employees, and $13 \%$ more than 500 employees. Figure 4.3 presents a descriptive analysis of the statements elaborated in the study to estimate the constructs of interest in the research.

The ex ante and ex post cost statements presented moderate major trend measurements with slightly negative asymmetries. Regarding the analytical 
dimensions of the transactions, it was found that the measures of the significant trend of the frequency of transactions were high (median and mode $=4$ ). At the same time, the values of the uncertainties (technological and market) were moderate (median and mode $=3$ ). On the other hand, the statements of specificity of human assets presented high values (median and mode $=4$ ) and moderate values with mild negative asymmetries for those of physical specificity (median and mode $=3$ ).

\section{(Figure 4.3)}

\section{DESCRIPTIVE ANALYSIS OF THE STATEMENTS* USED IN THE STUDY}

\begin{tabular}{|c|c|c|c|c|c|c|}
\hline & Questionnaire assertions & Median & Mode & Mean & SD & $\mathrm{N}$ \\
\hline \multirow{4}{*}{ 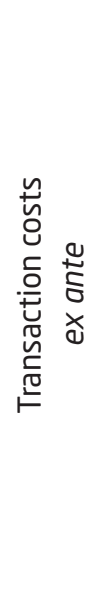 } & $\begin{array}{l}\text { 1. Resource expenditure for obtaining } \\
\text { information to establish trade agreements } \\
\text { with our partners is: }\end{array}$ & 3 & 3 & 2.5 & 1.23 & 122 \\
\hline & $\begin{array}{l}\text { 2. The time spent negotiating agreements } \\
\text { with trading partners before signing the } \\
\text { contract is: }\end{array}$ & 3 & 3 & 2.64 & 1.14 & 122 \\
\hline & $\begin{array}{l}\text { 3. The level of losses resulting from failures } \\
\text { to achieve an efficient initial agreement with } \\
\text { trading partners is: }\end{array}$ & 2 & 2 & 2.24 & 1.07 & 122 \\
\hline & $\begin{array}{l}\text { 4. The amount of resources spent during the } \\
\text { negotiation of agreements/drafting of trade } \\
\text { agreements with partners is: }\end{array}$ & 2 & 2 & 2.39 & 1.01 & 119 \\
\hline \multirow{4}{*}{ 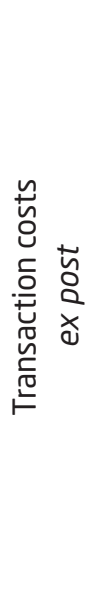 } & $\begin{array}{l}\text { 5. The expense of resources to monitor the } \\
\text { implementation of the activities of the trade } \\
\text { agreement with partners is: }\end{array}$ & 3 & 3 & 2.43 & 1.04 & 120 \\
\hline & $\begin{array}{l}\text { 6. The time spent with partners to resolve } \\
\text { conflicts of interest throughout the } \\
\text { implementation of the trade agreement is: }\end{array}$ & 3 & 3 & 2.7 & 1.13 & 121 \\
\hline & $\begin{array}{l}\text { 7. The expenditure of time/resources with } \\
\text { contractual adaptations of the commercial } \\
\text { agreement throughout its execution is: }\end{array}$ & 3 & 3 & 2.31 & 1.02 & 122 \\
\hline & $\begin{array}{l}\text { 8. Resource expenditures with incentives to } \\
\text { the team throughout the implementation of } \\
\text { the trade agreement are: }\end{array}$ & 3 & 3 & 2.43 & 1.04 & 120 \\
\hline
\end{tabular}




\section{(Figure 4.3 (continuation))}

\begin{tabular}{|c|c|c|c|c|c|}
\hline Questionnaire assertions & Median & Mode & Mean & SD & N \\
\hline $\begin{array}{l}\text { 9. The frequency of changes in the } \\
\text { technologies used in the activities/products } \\
\text { marketed by our company is: }\end{array}$ & 3 & 3 & 2.77 & 1.17 & 122 \\
\hline
\end{tabular}

\begin{tabular}{|c|c|c|c|c|c|c|}
\hline \multirow{5}{*}{ 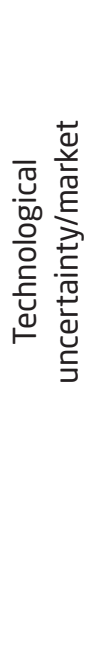 } & $\begin{array}{l}\text { 10. The chance of establishing a correct } \\
\text { forecast of the technical requirements } \\
\text { required in the partner's activities is: }\end{array}$ & 3 & 3 & 3.16 & 1.15 & 121 \\
\hline & $\begin{array}{l}\text { 11. The level of information provided by } \\
\text { partners on market trends is: }\end{array}$ & 3 & 3 & 3.43 & 1.16 & 122 \\
\hline & $\begin{array}{l}\text { 12. The forecast of market demand for the } \\
\text { products marketed in our company is: }\end{array}$ & 3 & 3 & 3.42 & 0.98 & 121 \\
\hline & $\begin{array}{l}\text { 13. The usual estimate of the volume of } \\
\text { products to be negotiated from one month } \\
\text { to another with the partners is usually: }\end{array}$ & 3 & 3 & 2.85 & 0.9 & 122 \\
\hline & $\begin{array}{l}\text { 14. The fluctuation in the consumption of } \\
\text { products marketed in our company from one } \\
\text { month to another is: }\end{array}$ & 3 & 3 & 2.93 & 0.96 & 121 \\
\hline \multirow{3}{*}{ 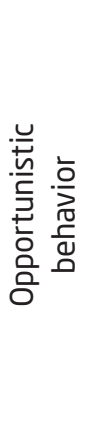 } & $\begin{array}{l}\text { 15. The difficulty in predicting the } \\
\text { performance of our partners in complying } \\
\text { with the agreed contracts is: }\end{array}$ & 3 & 3 & 2.55 & 1.09 & 122 \\
\hline & $\begin{array}{l}\text { 16. The level of use of contractual gaps by } \\
\text { partners to renegotiate conditions for their } \\
\text { benefit is: }\end{array}$ & 2 & 1 & 2.12 & 1.03 & 119 \\
\hline & $\begin{array}{l}\text { 17. Our partners exaggerate the costs they } \\
\text { incur to try to renegotiate conditions that } \\
\text { benefit them. }\end{array}$ & 2 & 1 & 2.12 & 1.05 & 120 \\
\hline \multirow{3}{*}{ 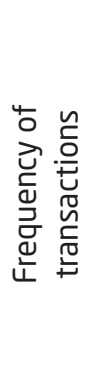 } & $\begin{array}{l}\text { 18. The frequency of recurring transactions } \\
\text { with current trading partners has been: }\end{array}$ & 4 & 4 & 3.76 & 1.02 & 119 \\
\hline & $\begin{array}{l}\text { 19. The frequency with which the same type } \\
\text { of business transaction occurs with the } \\
\text { same partner has been: }\end{array}$ & 4 & 4 & 3.89 & 0.95 & 122 \\
\hline & $\begin{array}{l}\text { 20. The number of previous partnerships of } \\
\text { the company with its main partners in other } \\
\text { areas of activity has been: }\end{array}$ & 4 & 4 & 2.99 & 1.22 & 120 \\
\hline
\end{tabular}

(continue) 


\section{(Figure 4.3 (conclusion))}

\begin{tabular}{|c|c|c|c|c|c|c|}
\hline & Questionnaire assertions & Median & Mode & Mean & SD & $\mathrm{N}$ \\
\hline \multirow{7}{*}{ 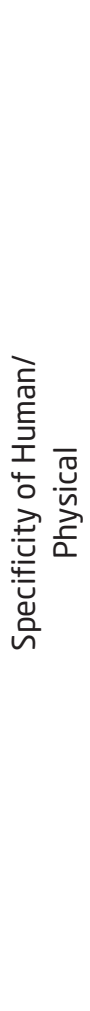 } & $\begin{array}{l}\text { 21. The need for specialized knowledge and } \\
\text { expertise of the technical team in the } \\
\text { activities in our field of activity is: }\end{array}$ & 4 & 5 & 4.05 & 1.03 & 122 \\
\hline & $\begin{array}{l}\text { 22. The need for additional investment in } \\
\text { training of the technical team in our field of } \\
\text { activity is: }\end{array}$ & 4 & 4 & 3.69 & 1.05 & 122 \\
\hline & $\begin{array}{l}23 \text {. The technical expertise required of our } \\
\text { employees to ensure the effective use of the } \\
\text { products we sell is: }\end{array}$ & 4 & 4 & 3.74 & 1.1 & 121 \\
\hline & $\begin{array}{l}\text { 24. The shelf life of the products is a } \\
\text { potential source for losses of investments in } \\
\text { transactions with partners is: }\end{array}$ & 3 & 3 & 2.97 & 1.09 & 118 \\
\hline & $\begin{array}{l}\text { 25. The need for investments in specific } \\
\text { physical spaces in transactions with trading } \\
\text { partners is: }\end{array}$ & 3 & 3 & 2.71 & 1.2 & 122 \\
\hline & $\begin{array}{l}\text { 26. Adaptations to commercial premises in } \\
\text { order to store products of specific and } \\
\text { controlled use are: }\end{array}$ & 3 & 3 & 2.78 & 1.3 & 120 \\
\hline & $\begin{array}{l}\text { 27. Investments in technological } \\
\text { infrastructure to facilitate the flow of } \\
\text { transactions with key partners are: }\end{array}$ & 3 & 3 & 3.22 & 1.15 & 122 \\
\hline
\end{tabular}

* Likert scale of five points (from 1 = very low to 5 = very high); SD - standard deviation.

Source: Elaborated by the author.

\subsection{Modeling and testing of the relationships proposed in the study}

The simultaneous processing of the proposed relationships between the constructs of asset specificity, uncertainty, frequency of transactions, opportunism, and transaction costs with Structural Equation Modeling (SEM) by the Maximum Likelihood Robust (ML ROBUST) method presented comparative and incremental adjustment indices $(\mathrm{NNFI}=0.838$; $\mathrm{CFI}=0.858$; IFI $=0.866)$ that were borderline concerning those recommended in the literature, due to the complexity of the model with many parameters to be estimated. 
Nevertheless, the CFI index value shows that $85.8 \%$ of the covariance of the indicators of the constructs under study can be reproduced in the population. On the other hand, the $\mathrm{SB} \chi^{2} / \mathrm{gl}$ ratio $=1.51(315.96 / 209)$, below the recommended value $\left(\mathrm{SB} \chi^{2} / \mathrm{gl}=2.5\right)$ and the absolute adjustment index RMSEA $=0.070$, within the $90 \%$ CI $(0.054 ; 0.085)$, reveal that the model met a moderate level of adjustment and allows the test, parsimoniously, of the relationships proposed in the study.

The processing of data modeling to test the relationship between opportunistic behavior and transaction costs presented $\beta=0.705 ; \mathrm{t}=3.524$; $\operatorname{sig}=0.001$, significant at the level of $5 \%$ significance, that is, an opportunistic behavior, reflected by the degree of predictability of the partner in fulfilling agreed contracts, the level of use of contractual gaps and exaggeration in the costs incurred to try to renegotiate conditions for its benefit, which significantly impacts transaction costs as set out in the first hypothesis and explains $49.7 \%$ of the variability of these costs. The result is in line with those presented in the qualitative study conducted by Oliveira (2018), in which the authors found the use of devices to question the fulfillment of the contract and force the reformulation of contractual clauses for their benefit, resulting in transaction costs to the contra party during the term of the contracts signed.

Regarding the effect of asset specificity on ex post transaction costs, the SEM processing presented $\beta=0.346 ; t=2.914$; sig $=0.006$ and an explanation coefficient $\mathrm{R}^{2}=12 \%$, indicating that, at the level of $5 \%$ significance, specificity has a significant impact on these costs as stated in the second hypothesis and explains $12 \%$ of the variability of these costs. Thus, the results support hypothesis 2 and show that the specificity of the assets used in the pharmaceutical retail business environment, in particular, the specificity in human assets and the specificity of physical/dedicated assets related to the qualification of employees and the adaptation of facilities for the ideal storage and control conditions of commercialized products, make the continuity of the relationship valuable and potentially subject to ex post transaction costs, in line with the arguments of Hoffmann et al. (2010), Hunter et al. (2005), Nooteboom et al. (1997), and Carson et al. (2006).

Regarding the relationship between uncertainty and ex ante transaction costs, the processing of the SEM presented $\beta=0.326$; $\mathrm{t}=2.068$; $\operatorname{sig}=0.014$ and $\mathrm{R}^{2}=10.6 \%$, indicating that, at the level of $5 \%$ significance, this dimension of transactions has a significant impact and explains $10.6 \%$ of the variability of ex ante transaction costs. Therefore, the results support the third hypothesis: the greater the uncertainty, the greater the ex ante transaction costs perceived by managers in the pharmaceutical retail business environment. 


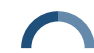

The result is in line with the arguments of Williamson (1985) and Azevedo (2000), regarding the difficulties for managers to understand the real functioning of the transaction environment, in particular, regarding the unpredictability of demand, fluctuation of consumption, frequency of changes, and technical requirements required in the commercialization of products. These difficulties were reflected by the indicators used in the study, which captured the increase in ex ante transaction costs and the complexity for the development of long-term partnerships and future renegotiations as argued by Bánkuti et al. (2008), Martins and Souza (2014), Silva and Brito (2013), and Folgueira et al. (2019).

(Figure 4.1.1)

MODELING OF THE RELATIONSHIPS OF THE PROPOSED THEORETICAL MODEL

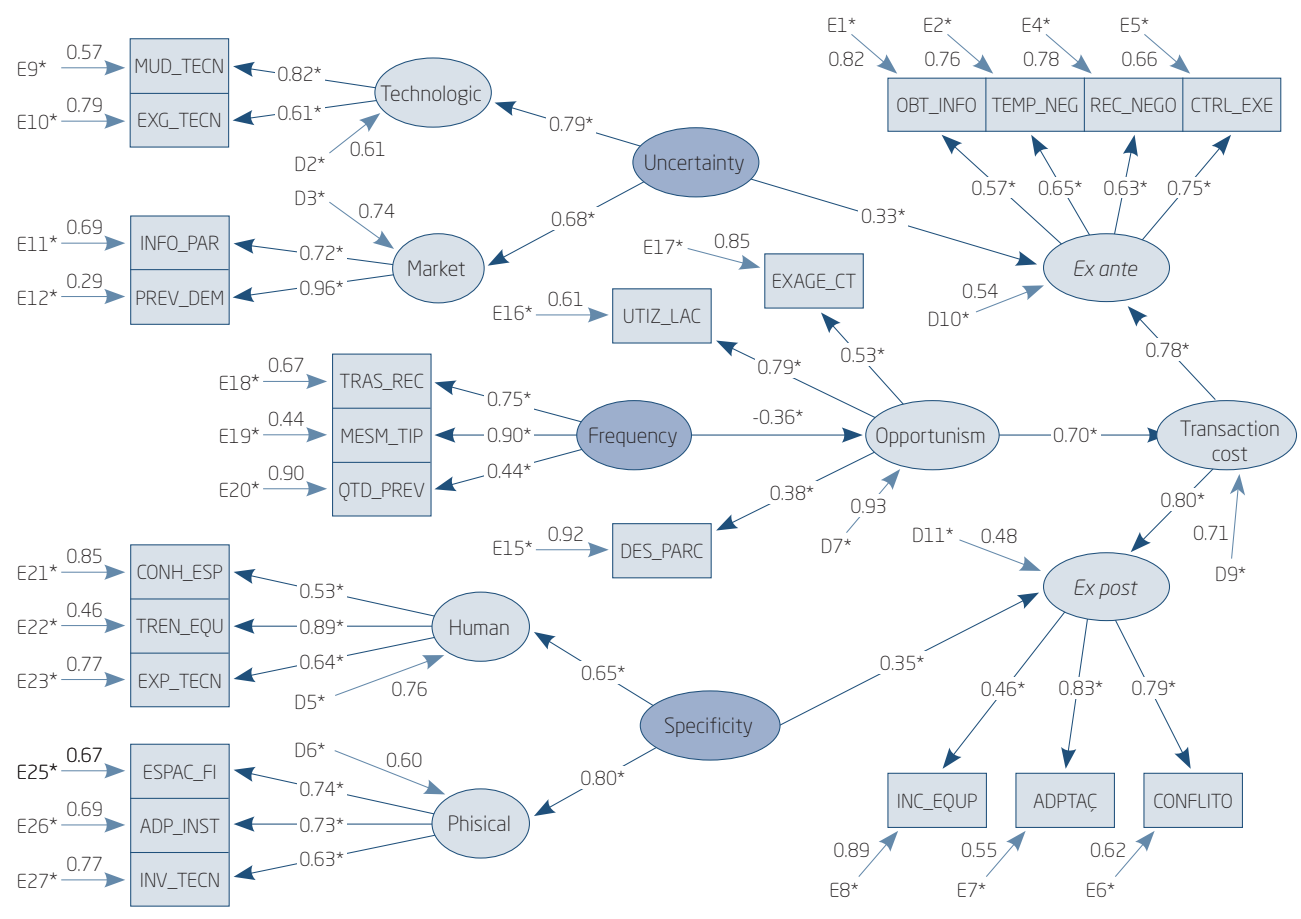

Source: Elaborated by the author.

Regarding the effect of the frequency of transactions on opportunistic behavior, the processing presented $\beta=-0.364 ; \mathrm{t}=-3.041$; sig $=0.004$ and an explanation coefficient $\mathrm{R}^{2}=13.2 \%$, that is, the frequency has a significant negative effect at the level of $5 \%$ significance and explains $13.2 \%$ of the 
variability of opportunistic behavior. Therefore, the higher the frequency of transactions, the lower the opportunistic behavior of the retail pharmaceutical environment.

The result supports hypothesis 4 and is in line with the arguments of Farina et al. (1997), Azevedo (2000), Bánkuti et al. (2008), Schubert and Waquil (2014), Santos and Souza (2017), Oliveira (2018), and Santos et al. (2019). That is, the frequency of transactions facilitates the gathering of greater knowledge between the parties, increases transparency and communication in negotiations, and provides the creation of a commitment based on trust and integrity that acts as a safeguard to minimize opportunistic actions between partners to obtain short-term gains in the transaction.

Therefore, within the sample of companies in the pharmaceutical retail business environment used in this study, it was found that: 1. opportunistic behavior influenced the transaction costs estimated as a two-dimensional construct from ex ante and ex post costs; 2 . the specificity of the assets influenced ex post transaction costs; 3 . uncertainty significantly influenced ex ante transaction costs; and finally, 4. the frequency of transactions influenced opportunistic behavior. The main results of the processing are summarized in Figure 4.1.2.

(Figure 4.1.2)

OVERVIEW OF SEARCH RESULTS

\begin{tabular}{lccccc}
\hline \multicolumn{1}{c}{ Hypothesis } & Coefficient & t student & Sig. & $\mathrm{R}^{2}$ & Results \\
\hline H1: Opportunism $\rightarrow$ Transaction cost & 0,705 & 3,524 & 0,001 & $49,7 \%$ & Supported \\
\hline H2: Specificity $\rightarrow$ Ex post transaction costs & 0,242 & 2,591 & 0,006 & $12,0 \%$ & Supported \\
\hline H3: Uncertainty $\rightarrow$ Ex ante transaction costs & 0,358 & 2,486 & 0,014 & $10,6 \%$ & Supported \\
\hline H4: Frequency $\rightarrow$ Opportunism & $-0,355$ & $-2,699$ & 0,008 & $13,2 \%$ & Supported \\
\hline
\end{tabular}

Source: Elaborated by the author.

The results obtained with the modeling of the data in structural equations show that the theoretical model's hypotheses were supported in the study. The indicators used to estimate the transactions and analytical dimensions of opportunism adequately reflected these constructs and their impacts on transaction costs.

\section{FINAL CONSIDERATIONS}

The study aimed to simultaneously test the relationships between asset specificity, uncertainty, frequency of transactions, and opportunistic behavior 
and their impacts on transaction costs in the pharmaceutical retail sector. To this end, based on the TCT literature, the characterized indicators adequately reflected both ex ante transaction costs and ex post costs, as well as the analytical dimensions of transactions and opportunistic behavior among the partners perceived by the managers surveyed. Thus, it was possible to test the theoretical model and estimate the proposed relationships between these constructs, thus, fulfilling the study's four specific objectives.

It is worth reflecting on the results obtained in the study, their contributions, and their implications in management actions. In this sense, the relationship between the frequency of transactions and opportunism is highlighted, a relationship that was little empirically tested in the TCT literature. The result ratified the qualitative studies undertaken in the field. It stressed the relevance of this analytical dimension to facilitate and gather greater knowledge between the parties, to increase transparency and communication in the negotiations, and to provide a reputation based on the trust and integrity of the partner. The result showed that the recurrence of transactions acts as a catalyst and a safeguard to minimize partners' opportunistic actions to short-term gains in the transaction, such as the use of contractual gaps and the exaggeration of the costs incurred to try to renegotiate conditions for their benefit.

It also verified, as in other quantitative studies, the significant effect of uncertainty on the variability of ex ante transaction costs. The uncertainty alters the degree of predictability of demand, fluctuation of consumption, and technical requirements required in the commercialization of products, making it difficult for managers to understand the prediction of contingencies in the transaction environment, demanding more significant expenditures of resources and time in the search for information to negotiate and establish commercial agreements.

The same was observed concerning the specificity of assets, which significantly impacted the ex post transaction costs perceived by managers in the business environment of the pharmaceutical retail sector. The specificity in human assets and the specificity of physical/dedicated assets related to the qualification of employees and the adaptation of facilities to the ideal conditions of storage and control of marketed products, situations that make the continuity of the relationship valuable, create greater dependence between partners and a greater propensity to ex post transaction costs with expenditures of time and resources to control the execution of activities, promote incentives to the team, and make contractual adaptations throughout the agreement. 
Therefore, the results of the study contribute to demonstrate that the uncertainty and specificity of the assets proved to be acceptable indicators of transaction costs. Simultaneously, the frequency of negotiations is a suitable catalyst for opportunism and, consequently, of potential transaction costs.

From the managerial perspective, these analytical dimensions can be used as parameters for the establishment of strategic actions to delineate the choice of efficient governance structures, as indicated by several studies undertaken in TCT, in particular, the frequency of transactions capable of providing the development of reliable and effective commitments to circumvent failures not covered by contracts, as well as to minimize opportunism and transaction costs in the context of the pharmaceutical retail sector.

Despite the progress with establishing a model capable of simultaneously testing the relationships proposed in this study, it is worth mentioning two limitations for the scope of its results. The first is related to the types of governance structures used in transactions between partners, which could expand knowledge about the effects of these dimensions on the structure choices in the studied sector. Although relevant, these structures were not targets of the study. The second is related to the assumption of limited rationality, also not contemplated in the scope of the study objectives. Together with the analytical dimensions of the transactions and the assumption of opportunistic behavior studied here, the assumption of limited rationality would constitute an analysis model with all the relationships proposed in the framework of TCT. This model would be able to test these relationships and their implications in decision-making regarding the adoption of efficient governance structures to minimize transaction costs in the organizations. This would be a challenge for the next years of research in this field of studies.

\section{CUSTOS DE TRANSAÇÃO NO VAREJO FARMACÊUTICO: IMPACTOS DO OPORTUNISMO E DIMENSÕES ANALÍTICAS DAS TRANSAÇÕES}

\section{RESUMO}

Objetivo: O estudo explora as relações preditivas das dimensões analíticas das transações e do comportamento oportunista sobre os custos de transação no varejo farmacêutico brasileiro. 
Originalidade/valor: O estudo contribui para o avanço das pesquisas empíricas sobre o tema e propõe indicadores modelados por equações estruturais para estimar simultaneamente os efeitos da incerteza, especificidade dos ativos e frequência das transações e do oportunismo nos custos de transação.

Design/metodologia/abordagem: Os custos de transação foram estimados com indicadores relativos aos custos de análise, elaboração e adaptação de contratos; as dimensões analíticas das transações com indicadores que refletem a especificidade de ativos humanos e ativos físicos/dedicados, a incerteza tecnológica e de mercado e a recorrência das transações, entre parceiros. Os dados coletados, via questionário eletrônico, foram processados com a técnica de Modelagem em Equações Estruturais.

Resultados: O processamento dos dados demonstrou a influência significativa da frequência das transações sobre o oportunismo e deste sobre os custos de transação. Confirmou-se também o impacto da incerteza nos custos de transação ex ante e da especificidade dos ativos nos custos ex post. Os resultados denotam a relevância das dimensões analíticas no arcabouço teórico da Teoria dos Custos de Transação e também a importância da frequência como um catalisador do oportunismo, podendo ser utilizada como parâmetro em ações estratégicas para criar compromissos confiáveis e contornar falhas contratuais não previstas no contexto do varejo farmacêutico.

\section{PALAVRAS-CHAVE}

Custos de transação. Varejo farmacêutico. Oportunismo. Dimensões das transações. Estruturas de governança.

\section{$\int$ REFERENCES}

Alencar, S. de C. (2018). Atributos de transação e estrutura de governança: Um estudo em empresas exportadoras do setor de fruticultura (Trabalho de conclusão de curso, Universidade Federal Rural do Semi-Árido, Mossoró, RN, Brasil). Recuperado de http://repositorio.ufersa.edu.br/handle/prefix/3377

Associação Brasileira de Redes de Farmácias e Drogarias (2019). Faturamento do grande varejo volta à casa dos dois dígitos. Revista Excelência, IX(9), 1-129. Recuperado de https://dedddc6a-a78f-4ab9-a66f-7e257251578b. filesusr.com/ugd/03661a_74d94da3a8084c5c9d00a7a11ba64a7f.pdf. 
Azevedo, P. F. (2000). Nova economia institucional: Referencial geral e aplicações para a agricultura. Agricultura em São Paulo, 47(1), 33-52.

Bánkuti, F. I., Souza, H. M. de, Filho, \& Bánkuti, S. M. S. (2008). Mensuração e análise de custos de transação arcados por produtores de leite nos mercados formal e informal da região de São Carlos, SP. Organizações Rurais e Agroindustriais, 10(3), 343-358.

Barthélemy, J., \& Quélin, B. (2006). Complexity of outsourcing contracts and ex post transaction costs: An empirical investigation. Journal of Management Studies, 43(8), 1775-1797.

Barzel, Y. (1997). Economic analysis of property rights (2nd ed.). Cambridge: Cambridge University Press.

Begnis, H. S. M., Arend, S. C., \& Alievi, R. M. (2017). Confiança, comportamento oportunista e quebra de contratos na cadeia produtiva do tabaco. Revista de Administração da Universidade Federal de Santa Maria, 10 (5), 888-907.

Bentler, P. M. (1995). EQS: Structural equations program manual. Encino, CA: Multivariate Software.

Bentler, P. M., \& Chou C. P. (1987). Practical issues in structural modeling. Sociological Methods and Research, 16(1), 78-117.

Bezerra, A. E. F. (2018). Atributos de transação e pressupostos comportamentais, à luz da teoria do custo de transação econômica: Um estudo multicaso no segmento salineiro do estado do Rio Grande do Norte (Trabalho de conclusão de curso, Universidade Federal Rural do Semi-Árido, Mossoró, RN, Brasil). Recuperado de http://repositorio.ufersa.edu.br/bitstream/prefix/3394/2/Antonio EFB_ART.pdf

Caleman, S. M. Q., Sproesser, R. L., Lima, D. O., \& Tredezin, C. A. O. (2006). Mecanismos de governança em sistemas agroalimentares: Um enfoque na mensuração dos custos de transação. Revista de Economia e Agronegócio, 4(2), 219-240.

Carson, S. J., Madhok, A., \& Wu, T. (2006). Uncertainty, opportunism, and governance: The effects of volatility and ambiguity on formal and relational contracting. The Academy of Management Journal, 49(5), 1058-1077.

Claro, D. P., \& Claro, P. B. O. (2004). Gerenciando relacionamentos colaborativos com fornecedores. Revista de Administração de Empresas, 44(4), 68-79.

Coase, R. (1937). The nature of the firm. Economica, 4(16), 386-405.

Cunha, C. F. D., Saes, M. S. M., \& Mainville, D. Y. (2015). Custo de transação e mensuração na escolha da estrutura de governança entre supermercados e produtores agrícolas convencionais e orgânicos no Brasil e nos EUA. Gestão \& Produção, 22(1), 67-81. 
Diamantopoulos, A., \& Winklhofer, H. M. (2001). Index construction with formative indicators: An alternative to scale development. Journal of Marketing Research, 38(2), 269-277.

Farina, E. M. M. Q., Azevedo, P. F. A., \& Saes, M. S. M. (1997). Competitividade: Mercado, estado e organizações. São Paulo: Singular.

Federação Brasileira das Redes Associativistas e Independentes de Farmácias (2018). Varejo farmacêutico fatura R $\$ 120,3$ bilhões em 2018 e cresce $11,76 \%$. Recuperado de https://www.febrafar.com.br/varejo-farmaceuticocresce-1176/

Fernandes, J. L. N. (2020). Mensuração dos custos de transação na composição dos custos totais do ponto de açaí. Cadernos CEPEC, 9(1), 61-82. doi:10.18542/cepec.v9i1.8932

Finney, S. J., \& DiStefano, C. (2006). Non-normal and categorical data in structural equation models. In G. R. Hancock \& R. O. Mueller (Eds.), A second course in structural equation modeling (pp. 269-314). Greenwich: Information Age Publishing.

Folgueira, R. S., Silva, A. L. P., \& Carvalho, C. E. (2019). Economia do compartilhamento e custos de transação: Os casos Uber e Airbnb. Pesquisa \& Debate - Revista do Programa de Estudos Pós-Graduados em Economia Política, 31(55), 87-135.

Furubotn, E., \& Richter, R. (2000). Institutions and economic theory: The contribution of the new institutional economics. Ann Arbor, MI: Michigan Press.

Grover, V., \& Malhotra, M.K. (2003). Transaction cost framework in operations and supply chain management research: Theory and measurement. Journal of Operations Management, 21 (4), 457-473.

Hair, J. F., Jr., Anderson, R. E., Tatham, R. L., \& Black, M. C. (2009). Análise multivariada de dados (6a ed.). Porto Alegre: Bookman.

Hoffmann, W. H., Neumann, K., \& Speckbacher, G. (2010). The effect of interorganizational trust on make-or-cooperate decisions: Disentangling opportunism-dependent and opportunism-independent effects of trust. European Management Review, 7(2), 101-115.

Hunter, L. C., Webster, E., \& Wyatt, A. (2005). Techniques for measuring intangible capital: A review of current practice. The Australian Accounting Review, 15(2), 4-21.

Kilinsky, P. I., \& Souza, R. P. (2016). Percepções sobre custos de transação em contratos de terceirização: Estudo aplicado em uma instituição financeira de varejo. Anais do Encontro da Anpad, 40. 
Knight, F. H. (2002). Risk, uncertainty and profit (5th ed.). Washington: Beard Books.

Lazzarini, S. G., Zylbersztajn, D., \& Takaki, F. S. (1998). Inovações contratuais em mercados futuros: $\mathrm{O}$ caso do boi gordo na BM\&F. Revista de Administração Contemporânea, 2(3), 7-26. doi:10.1590/S1415-65551998000300002

Lodi, G. (2018). A teoria dos custos de transação e sua relevância para as decisões organizacionais estratégicas de produzir ou terceirizar diante da Lei n. 13.429, de 31 de março de 2017. Ciências Sociais Aplicadas em Revista, 18(35), 240-259.

Macher, J. T., \& Richman, B. D. (2008). Transaction cost economics: An assessment of empirical research in the social sciences. Business and Politics, 10(1), 1-63.

Martins, D. de L. C. da C., \& Souza, J. P. de (2014). Atributos da transação e mensuração, e sua influência nas relações entre cooperados e cooperativas em sistemas agroindustriais suinícolas. Revista de Administração Mackenzie, 15(3),69-100. doi:10.1590/1678-69712014/administracao.v15n3p69-100

Melo, A. D., Sales, L. B., Oliveira, A. M. de, Almeida, C. A. S., \& Souza, F. C. (2018). Atributos de transação e pressupostos comportamentais: Um estudo multicaso nas empresas exportadoras do segmento meloeiro no estado do Rio Grande do Norte. Anais do Congresso Brasileiro de Custos, 25. Recuperado de https://anaiscbc.emnuvens.com.br/anais/article/view/4428

Nooteboom, B., Berger, H., \& Noorderhaven, N. G. (1997). Effects of trust and governance on relational risk. Academy of Management Journal, 40(2), 308-338.

Nunnally, J. C., \& Bernstein, I. H. (1994). Psychometric theory (3rd ed.). New York: McGraw-Hill.

Oliveira, F. P. G. (2018). Os custos ex ante $e$ ex post, na relação cliente e empresa, à luz da teoria do custo de transação econômica: Um estudo de caso em uma instituição de ensino superior no estado do Ceará (Trabalho de conclusão de curso, Universidade Federal Rural do Semi-Árido, Mossoró, RN, Brasil). Recuperado de http://repositorio.ufersa.edu.br/handle/prefix/3380

Oliveira, O. das C., Sales, L. B., Oliveira, A. M. de, Bezerra, A. E. F., \& Souza, M. O. de, Neto (2019). Custo de transação econômica e planejamento tributário. Revista Ambiente Contábil, 11 (2), 175-198. Recuperado de https:// periodicos.ufrn.br/ambiente/article/view/13451/11855

Pilling, B. K., Crosby, L. A., \& Jackson, D. W. (1994). Relational bonds in industrial exchange: An experimental test of the transaction cost economic framework. Journal of Business Research, 30(3), 237-251. 
Polski, M. M., \& Kearney, A. T. (2001). Measuring transaction costs and institutional change in the US commercial banking industry [Discussion Paper]. Indiana: Institute for Development Strategies.

Raifur, L., \& Garcias, P. M. (2008). A economia dos custos de transação e as transações no mercado de derivativos agropecuários. Anais do Congresso Brasileiro de Custos, Curitiba.

Riordan, M. H., \& Williamson, O. E. (1985). Asset specificity and economic organization. International Journal of Industrial Organization, 3(4), 365-378.

Santos, E. J., Lourenzani, W. L., \& Lourenzani, A. E. B. S. (2019). Coordenação do Sistema Agroindustrial do Urucum na Microrregião de Dracena, estado de São Paulo. Revista Brasileira de Gestão e Desenvolvimento Regional, 15(1), 110-123.

Santos, R. H., \& Souza, J. P. (2017). Estruturas de governança como atenuantes do poder de comprador: Um modelo conceitual. Revista Conbrad, 2(1), 216-236.

Schubert, M. N., \& Waquil, P. D. (2014). Análise dos custos de transação nas cooperativas da cadeia produtiva do leite no oeste de Santa Catarina. Organizações Rurais \& Agroindustriais, 16(4), 435-449.

Serigati, F., \& Azevedo, P. F. (2014). How to indirectly measure market transaction costs. Annual ISNIE Conference, 18.

Silva, A. A., \& Brito, E. P. (2013). Incerteza, racionalidade limitada e comportamento oportunista: Um estudo na indústria brasileira. Revista de Administração Mackenzie, 14(1), 176-201. doi:10.1590/S1678-697120130 00100008

Simon, H. (1958). Administrative behavior (2nd ed.). New York: Macmillan.

Skarmeas, D., Katsikeas, C. S., \& Schlegelmilch, B. B. (2002). Drivers of commitment and its impact on performance in cross-cultural buyers-seller relationships: The importer's perspective. Journal of International Business Studies, 33(4), 757-783.

Williamson, O. E. (1979). Transaction-cost economics: The governance of contractual relations. Journal of Law and Economics, 22 (2), 233-261.

Williamson, O. E. (1985). The economic institutions of capitalism. New York: Free Press.

Williamson, O. E. (1991). Comparative economic organization: The analysis of discrete structural alternatives. Administrative Science Quarterly, 36(2), 269-296. 
Zylbersztajn, D. (2010). Entry costs and quality of business environment: A critical analysis. Revista de Administração Mackenzie, 11(5), 151-161.

Zylbersztajn, D., \& Graça, C. T. (2003). Costos de formalización de las empresas: Medición de los costos de transacción en Brasil. Revista de Economía Institucional, 5(9), 146-165.

\section{AUTHOR NOTES}

Adilson A. Silva, Ph.D. from the Graduate Program in Business Administration, Mackenzie Presbyterian University (UPM).

Adilson A. Silva is now a professor and researcher at the Center for Social and Applied Sciences (CCSA) of UPM.

Correspondence concerning this article should be addressed to Adilson A. Silva, Rua Jacareí, 188, Jardim Alvorada, Santo André, São Paulo, Brasil, CEP 09180-500.

E-mail: adilson.asilva@mackenzie.br

\section{EDITORIAL BOARD}

\section{Editor-in-chief}

Gilberto Perez

Associate editor

Francisco Américo Cassano

Technical support

Vitória Batista Santos Silva

\section{EDITORIAL PRODUCTION}

Publishing coordination

Jéssica Dametta

Language editor

Daniel de Almeida Leão

Layout designer

Emap

Graphic designer

Libro 